JOURNAL OF SECURITY AND SUSTAINABILITY ISSUES

ISSN 2029-7017 print/ISSN 2029-7025 online

2019 December Volume 9 Number 2

http://doi.org/10.9770/jssi.2019.9.2(16)

Scopus

\title{
THE IMPACT OF GOVERNMENT EXPENDITURES, GROSS CAPITAL FORMATION, TRADE, AND PORTFOLIO INVESTMENT ON THE ECONOMIC GROWTH OF ASEAN ECONOMIES
}

\author{
Kittisak Jermsittiparsert ${ }^{1}$, Sakapas Saengchai ${ }^{2}$, Chanathat Boonrattanakittibhumi ${ }^{3}$, \\ Thitinan Chankoson ${ }^{4}$ \\ ${ }^{1}$ Social Research Institute, Chulalongkorn University, Bangkok, Thailand. \\ ${ }^{2}$ Faculty of Humanities and Social Sciences, Suan Sunandha Rajabhat University, Bangkok, Thailand \\ ${ }^{3}$ Business and Administration Department, King Moungkult's Institute of Technology, \\ Prince of Chumphon Campus, Chumphon, Thailand \\ ${ }^{4}$ Faculty of Business Administration for Society, Srinakharinwirot University, Bangkok, Thailand \\ E-mails: ${ }^{1}$ kittisak.j@chula.ac.th (correspondingauthor); ${ }^{2}$ sakapas.sa@ssru.ac.th;

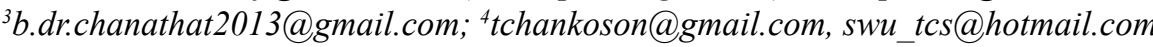

Received 10 January 2019; accepted 18 September 2019; published 30 December 2019

\begin{abstract}
This paper examines the impact of public spending on ASEAN-5 countries economic development. The purpose of this study is to provide evidence, reference and contribute to the knowledge about government spending and economic growth. This study involves ASEAN-5 countries. The countries are Thailand, Singapore, Indonesia, Philippines and Malaysia. The countries are chosen because there is a lack of study of government expenditure for ASEAN-5 countries using panel data. The data covers from year 1990 to 2014. The data is retrieved from the World Development Indicators (World Bank). The dependent variable is gross domestic product (GDP). GDP is used to measure economic growth. The main independent variable is government expenditure. The other independent variables are gross capital formation, portfolio investment, labor, trade, total reserve and gross savings. A clear understanding about inter-linkages between government spending and economic growth will help the government in making better decision for the country. As ASEAN countries have responsibility for ASEAN Economic Community (AEC) Blueprint 2025 to meet its objectives, ASEAN governments are expected to effectively monitor the public spending as fiscal instrument in stimulating economic growth. Government expenditure may become unproductive if misallocating and using it in excess. From this study, there is evidence that government expenditure has impact on economic growth. Future research is expected to expand the investigation to other composition of government spending such as education, defense and infrastructure expenditures instead of using general government final consumption expenditures.
\end{abstract}

Keywords: ASEAN; economic growth; trade, capital formation

Reference to this paper should be made as follows: Jermsittiparsert, K., Saengchai, S., Boonrattanakittibhumi, C., Chankoson, T. 2019. The impact of government expenditures, gross capital formation, trade, and portfolio investment on the economic growth of ASEAN economies, Journal of Security and Sustainability Issues 9(2): 571-584. http://doi.org/10.9770/jssi.2019.9.2(16)

JEL Classifications: F23, Q24, E22

\section{Introduction}

Numerous of previous research have been conducted regarding government spending (GSP) and economic growth (ECNG). This relationship is an important part studied in public economics. The relationship was first investigated empirically by Wagner more than a hundred years ago. Wagner introduced the 'law of the expanding state role'. It is also called Wagner's Law. Wagner's Law suggests that public spending may cause economic progress. According to Wagner, GSP is positively responding to ECNG. Increasing income of a country will increase public sector's size of the country. Wagner also found that public spending is income-elastic. Wagner suggests that consumption of elasticity for public good is greater than one and elasticity consumption from 
private sector is less than one. Most of public goods and services are considered as civil goods. Education and health care services are examples of civil goods.

As income increases, the demand for civil goods increases faster than increment in income level. Therefore, public spending should also increase faster compared to increment in national income due to a greater demand of enactment, laws and policy of civil goods (Pradhan, Arvin, \& Norman, 2015). Wagner concluded that the economic development leads to more administrative functions of the states; increase in allocation of money in social and cultural goods and services; and increase in proper administrative and bureaucratic controls (Demirci, Soon, \& Wallace, 2016; Okon \& Monday 2017; Sasongko et al. 2019). Pradhan et al. (2015) agree with Wagner's Law. Naseer (2019) conclude that governments spend money for certain goals. For example, to increase per-capita income. Therefore, they have responsibility to ensure different components of expenditure meet the objectives. However, there is no exact economic theory or empirical evidence to measure the correct composition of PEX in boosting ECNG.

If one market fails to provide public goods, then only governments will justify their intervention for the related market. There is no guidelines or operational rules in their decision making about the spending that need to be cut in public sector. Wagner suggests that public expenditure (PEX) has impact on ECNG where public spending expands faster than national income. The causality runs from income to GSP. However, according to Keynesian macroeconomic viewpoint, the causality runs from public spending to income. Keynesian theory views the GSP as an instrument policy to increase ECNG. The Keynesian viewpoint believes that governments should spend more and reduce tax to stimulate economy downturn. As the economy slows down, the unemployment rate and economic dislocation is high. In that case, governments should increase certain public sector programmed (Demirci et al., 2016; Nazal, 2017; Baltgailis, 2019; Tung, 2019).

The issue of GSP and ECNG is crucial for developing countries. The public sector usually uses a relatively large share of society's economic resources (Odhiambo, 2018; Mohamed, Rasheli \& Mwagike 2018). As mentioned by Wagner's Law, public spending will increase as per capita income increases. A growing economy will cause administrative and protective functions of the state to expand. Higher public spending is required to maintain law and order as well as socio-economic regulation. As complexity of economic life and urbanization increases, the government need to spend more on regulations.

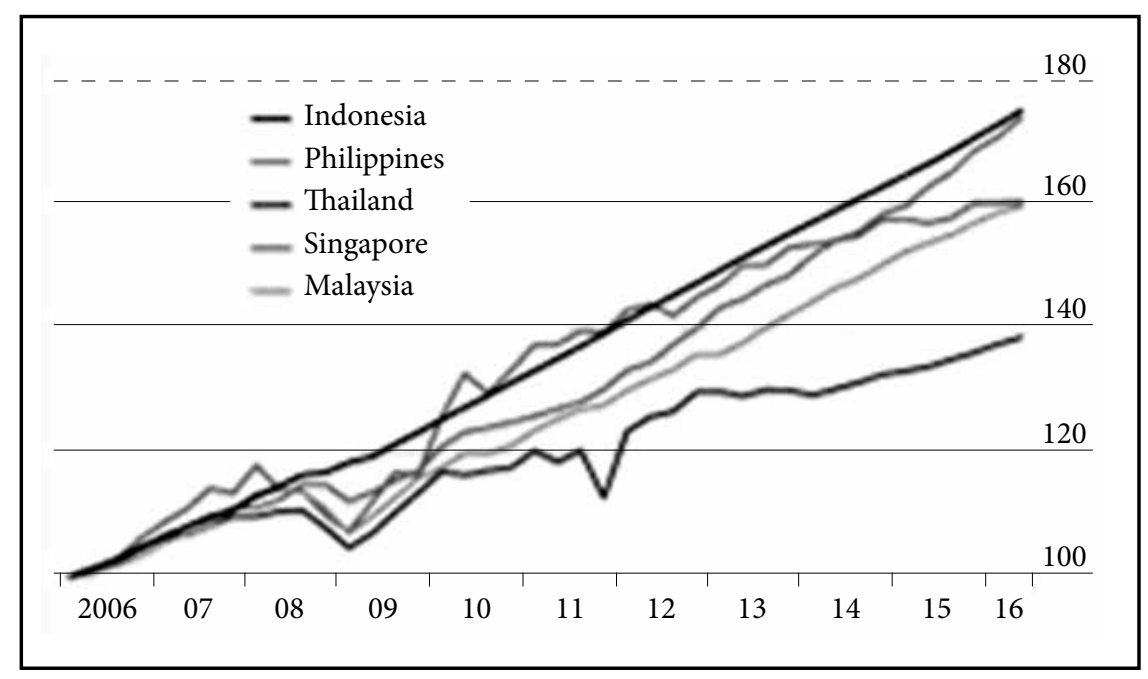

Figure 1. ECNG in Asean economies

Furthermore, public spending on cultural and welfare services are also increased during industrialization. This is due to high demand or high-income elasticity for cultural and welfare services, and usually these services are provided by government. PEX for these services will increase rapidly as the demand of these services increase. In addition, technological needs require larger amounts of capital. The government has to provide the capital 
funds to finance large-scale capital expenditures since the private sector does not have the capacity to provide the funds; as stated by Odhiambo (2018) and Pradhan et al. (2015).

GSP is increasing over the years. There is a need to test the relationship between government expenditure and economic development of a country. Pradhan et al. (2015) agree that government expenditure has a positive impact on ECNG. In some cases, government expenditure does not have a significant relationship with ECNG. Naseer (2019) conclude that productive PEXs may become unproductive if misallocating and using it in excess.

Numerous of previous research have been conducted regarding GSP and ECNG. This relationship is an important part studied in public economics. The relationship was first investigated empirically by Wagner more than a hundred years ago. Wagner introduced the 'law of the expanding state role'. It is also called Wagner's Law. Wagner's Law suggests that public spending may cause economic progress. According to Wagner, GSP is positively responding to ECNG. Increasing income of a country will increase public sector's size of the country (Kleven, Kreiner, \& Saez, 2016; Mohammed, 2017). Wagner also found that public spending is income-elastic. Wagner suggests that consumption of elasticity for public good is greater than one and elasticity consumption from private sector is less than one. Most of public goods and services are considered as civil goods. Education and health care services are examples of civil goods. As income increases, the demand for civil goods increases faster than increment in income level. Therefore, public spending should also increase faster compared to increment in national income due to a greater demand of enactment, laws and policy of civil goods (Pradhan et al., 2015; Mujtaba et al., 2018).

Wagner concluded that the economic development leads to more administrative functions of the states; increase in allocation of money in social and cultural goods and services; and increase in proper administrative and bureaucratic controls (Demirci et al., 2016). Pradhan et al. (2015) agree with Wagner's Law. Naseer (2019) conclude that governments spend money for certain goals. For example, to increase per-capita income. Therefore, they have responsibility to ensure different components of expenditure meet the objectives. However, there is no exact economic theory or empirical evidence to measure the correct composition of PEX in boosting ECNG. If one market fails to provide public goods, then only governments will justify their intervention for the related market (Russell et al., 2017; Ryan \& Robert, 2017). There is no guidelines or operational rules in their decision making about the spending that need to be cut in public sector.

Wagner suggests that PEX has impact on ECNG where public spending expands faster than national income. The causality runs from income to GSP (Thabane \& Lebina, 2016). However, according to Keynesian macroeconomic viewpoint, the causality runs from public spending to income. Keynesian theory views the GSP as an instrument policy to increase ECNG. The Keynesian viewpoint believes that governments should spend more and reduce tax to stimulate economy downturn. As the economy slows down, the unemployment rate and economic dislocation is high. In that case, governments should increase certain public sector programmes (Demirci et al., 2016; Mulyani, 2017).

The Association of Southeast Asian Nations (ASEAN) countries were held their first meeting in Bangkok, Thailand on 8 August 1967. There were five countries joining ASEAN: Thailand, Singapore, Philippines, Indonesia and Malaysia. The first ASEAN meeting was called ASEAN declaration or Bangkok declaration. Then, another five countries joined ASEAN. This paper examines the impact of public spending on ASEAN-5 countries economic development. The purpose of this study is to provide evidence, reference and contribute to the knowledge about GSP and ECNG. It is expected to clarify the importance of fiscal policy and other macroeconomic variables in strengthening the economy for ASEAN-5 countries. A clear understanding about inter-linkages between GSP and ECNG will help the government in making better decision for the country. As ASEAN countries have responsibility for ASEAN Economic Community (AEC) Blueprint 2025 to meet its objectives, ASEAN governments are expected to effectively monitor the public spending as fiscal instrument in stimulating ECNG. Government expenditure may become unproductive if misallocating and using it in excess, as suggested by Naseer (2019). 
This study involves ASEAN-5 countries. The countries are Thailand, Singapore, Indonesia, Philippines and Malaysia. The countries are chosen because there is a lack of study of government expenditure for ASEAN-5 countries using panel data. The data covers from year 1990 to 2014. The data is retrieved from the World Development Indicators (World Bank). The dependent variable is gross domestic product (GDP). GDP is used to measure ECNG. The main independent variable is government expenditure. The other independent variables are gross capital formation, portfolio investment, labor, trade, total reserve and gross savings.

\section{Literature Review}

Researchers have used various methods for explaining the effects caused by government expenditures on ECNG. For analyzing GSP ECNG relationship in 15 European Union economies, Sáez, Álvarez-García, and Rodríguez (2017) employed random and fixed effect approaches and found positive impact of UK and Portugal's government expenditure on their ECNG. However, in case of Italy, Austria, Sweden and Finland, results revealed the existence of negative association among ECNG and GSP, whereas, no significant relationship is obtained, for the rest of the countries. Furthermore, Ayinde, Ilori, Ayinde, and Babatunde (2015) investigated the association among recurrent expenditures, different government's sources of revenues, ECNG and capital expenditure in Nigerian economy, for a period of 1981-2011, using co-integration, unit root test, combined estimators' analysis and error-correction mechanism. The statistical findings suggested that recurrent expenditure, capital expenditures, federal retained revenue, and oil revenues positively influence ECNG in Nigeria. Another study (Alexiou, 2009; Negrut, 2017) examined the GSP and ECNG relationship for 7 South Eastern European (SEE) countries namely Serbia, Bulgaria, FYROM, Bosnia, Croatia, Romania, and Albania, by employing panel data for the time period 1995-2005. As a result, positive impact of GSP on private investment, capital formation, trade openness, and development assistance is found on the ECNG in these economies, however, insignificant relationship is found between ECNG and population growth.

Using time series approach, Pradhan et al. (2015), Odhiambo (2018) and Naseer (2019) found the same result for the relationship between government expenditure and ECNG. Pradhan et al. (2015) investigate the relationship in Greek from year 1960 to 2001, Fawwaz (2016) performed their study in Nigeria from year 1977 to 2012 and Odhiambo (2018) test the relationship for ASEAN-5 countries from year 1960 to 2002. They agree that there is a long-run positive impact of GSP on economy of these countries. Pradhan et al. (2015) tested income elasticity by using gross national product and per capita gross national product as independent variable; and total and partial public spending as dependent variable. The result confirms Wagner's Law, however, a bidirectional causality is found from the Granger-causality test among ECNG and PEX.

According to Keynesian macroeconomic viewpoint, government expenditure does Granger cause ECNG. The causality direction runs from government expenditure to economic activities. In Keynesian hypothesis, ECNG is the outcome of government expenditure. His viewpoint is contrast to Wagner's Law. Keynes states that government expenditure is an exogenous factor. Government expenditure is a tool of policy instrument to stimulate the ECNG (Pinder, 2017). From his perspective, PEX will contribute positively to ECNG. If a government spend more, it will give multiplier effects on aggregate demand. Keynes suggests that government could increase the economy during economic downturns by lending money from the private sector (Fawwaz, 2016). Few scholars found that Keynesian hypothesis explained the impact of GSP and ECNG. For example, Pinder (2017) and Ajayi and Aluko (2016). Ajayi and Aluko (2016) examines the impact of real government expenditure and real money supply on Thailand aggregate real output or real GDP from year 1993 to 2006. Using Granger causality test, the result shows that aggregate government expenditures cause ECNG.

On the other hand, Pinder (2017) tests the US federal government data to find a clear result about the impact of GSP on ECNG. The sample of the data is from year 1947 to 2002. The data includes human resources, national defense, physical resources and other expenses, and also net interest payment. The outcome shows no causal relationship between GDP and national defense expenditure. National security does not affect the economy activities. There is also two-way direction causality between physical resources, net interest payment and ECNG. 
However, unidirectional causality occurs between human resources and other expenditure and ECNG. The causality runs from human resources expenditure to GDP and GDP to other expenditure. The results more consistent to support Keynesian's theory. Fasoranti (2015) investigates the impact of government expenditure on ECNG in Malaysia by comparing two hypotheses; The Wagner's Law and Keynesian hypothesis. The data of real GDP and real government expenditure are obtained from World Development Indicators (World Bank) from year 1960 to 2005. Using time series technique, the result shows that Granger's non-causality tests have two-way causal relationship between government expenditure and ECNG. His study also supports both Wagner's Law and Keynesian law in Malaysia

The study of Fawwaz (2016) shows that government expenditure on education is the most crucial spending in Nigeria. They suggest that the government should be focus more on education expenditure for the country. Odhiambo (2018) confirms that only Philippines has unidirectional causality from government expenditure to national income.

\subsection{Theoretical Review}

In order to empirically analyze ECNG-government expenditure relationship in Malaysian economy, Fasoranti (2015) provided detailed explanation of Keynesian and Wagnerian hypothesis. Wagner's Law which is also termed as the Law of increasing state spending is a classical approach which suggests that GSP constantly increases with higher levels of ECNG. Here GSP considers as an economic progress outcome and is taken as endogenous factor. Thus, according to Pinder (2017), PEX is assumed to be a consequence or outcome resulting from economic activities. In addition, a few other studies Jakovljevic (2016) also attempted to discover the nature of ECNG and GSP relationship, through performing times series analysis. Author tried to capture whether PEX affects ECNG of Sudan, during 1970-2010, similarly the effects on Taiwan, South Korea, USA, Thailand, Japan, and UK's ECNG were studied by Wang, Li, and Fang (2018) for the period of 1951-1996; in addition, the long-run national income growth and public spending relationship is also examined by Jakovljevic (2016) for G7 economies, which includes Italy, France, United States, Japan, Canada, Germany, and United Kingdom. They obtained data for a period of 1960-1993. Thus, all the above studies obtained findings that were consistent with the Wagner's Law.

Contrarily, the Keynesian macroeconomic theory states that GSP increases the national income and ECNG, therefore implying that public spending granger cause country's ECNG, running from GSP to the economic activities. The Keynesian theory advocates that ECNG is the resultant outcome of government expenditure, which is inconsistent with the Wagner's Law. Moreover, Keynes considered government expenditure as the external factor. Thus, according to Pinder (2017), GSP is one of the policy instruments for achieving desirable level of ECNG. According to Keynesian theory, PEX positively contributes to the ECNG, such that more GSP will boost aggregate demand and output through multiplier effects. In addition, it has also been suggested that during economic downturns, government can play its role by lending from external sources or from the private sector to expand the economic activities. Afterwards, money is sent back to private sector by initiating spending programs. Thus, higher GSP tends to increase profitability, investment, and employment (Fawwaz, 2016; Njegovanovic, 2018).

Few scholars found that Keynesian hypothesis explained the impact of GSP and ECNG. For example, Pinder (2017) examines the impact of real government expenditure and real money supply on Thailand aggregate real output or real GDP from year 1993 to 2006. Using Granger causality test, the result shows that aggregate government expenditures cause ECNG.

On the other hand, Pinder (2017) tests the US federal government data to find a clear result about the impact of GSP on ECNG. The sample of the data is from year 1947 to 2002. The data includes human resources, national defense, physical resources and other expenses, and also net interest payment. The outcome shows no causal relationship between GDP and national defense expenditure. National security does not affect the economy activities. There is also two-way direction causality between physical resources, net interest payment and ECNG. However, unidirectional causality occurs between human resources and other expenditure and ECNG. The 
causality runs from human resources expenditure to GDP and GDP to other expenditure. The results more consistent to support Keynesian's theory. Fasoranti (2015) investigates the impact of government expenditure on ECNG in Malaysia by comparing two hypotheses; The Wagner's Law and Keynesian hypothesis. The data of real GDP and real government expenditure are obtained from World Development Indicators (World Bank) from year 1960 to 2005. Using time series technique, the result shows that Granger's non-causality tests have two-way causal relationship between government expenditure and ECNG. His study also supports both Wagner's Law and Keynesian law in Malaysia.

By using a time-series and cross-sectional data for 43 developing economies for 20-years i.e. during 19701990, Naseer (2019) added defense expenditures, total central government expenses (both capital \& current), transport, health, communication and education as the set of independent variables, whereas the average of five-year forward moving per-capita real GDP growth is included in the study as the dependent variable. Hence, the results indicate significant positive association among ECNG and share of current expenditure.

However, a few researchers such as, Nishiyama (2019) and Ajayi and Aluko (2016) advocated that GSP does not positively contributes to the ECNG. Ajayi and Aluko (2016) attempted to examine whether actual human capital creation and ECNG are affected by government expenditure on human capital, in health and education sectors. For this purpose, he incorporated a cross-sectional data of 84 non-Communist developing economies and reported that no significant relationship is found among ECNG and GSP on human capital, in addition, limited impact is observed for GSP on the actual health and education level. Similar findings were obtained by another study (Okon, 2017; Nishiyama, 2019), who employed Granger causality test for determining the nature of causality between real per capita GDP growth rate and GSP in GDP, and used time series analysis for the statistical estimation. The results of Vector Autoregressive (VAR) model indicated that GSP has no significant impact on the per capita real output growth. It has also been suggested in this study that the deficits in Saudi Arabia are generally handled by reducing the governments' size and by minimizing its activities in the economy (Abdul Hadi et al., 2019).

Contrarily, a negative relationship is found in few other studies (Donou-Adonsou, 2019; Ruiz, 2018) among ECNG and government expenditure. In an attempt to observe the empirical regularities in post-war ECNG, Ruiz (2018) included 113 economies and employed a set of cross-sectional and time series data for these economies. The results indicate that there exists significant negative association among ECNG and GSP. However, for Central and South America and Africa, negative correlation is obtained for economic development and political repression. In another study, Donou-Adonsou (2019) employed the data for 98 economies, for a period of 1960-1985 and reported significant positive political stability and ECNG relationship, and a negative association between a proxy variable for market distortions and economic development. Pastor (2019) conducted a research including 24 economies to make a comparison of the public and private investment effects on the ECNG of these economies, during 1970-1979. It is found that ECNG has a relatively larger influence of private investment as compared to public investment. Although, ECNG has positive indirect influence of public investment. The infrastructural spending, such as, electricity, schools, telecommunication, and roads strongly influence the private capital formation.

Scholar examined whether any positive or negative association exists among domestic investment, foreign direct investment, ECNG, and savings, and included the data of 16 Sub-Saharan African (SSA) economies, during 1981-2011. The study employed Granger causality test and VAR estimation analysis and found a one-way causality i.e. from FDI to domestic investment, and ECNG and from savings towards the ECNG, whereas, a two-causality is also observed among domestic investment and growth and domestic investment and savings. Thus, these findings indicate that growth plays a significant role in explaining FDI, savings for explaining domestic investment and the significant role of domestic investment in explaining savings pattern. Besides, the study by Sekantsi and Kalebe (2015) also examined the cause and effect relationship among savings, investment and ECNG, in Lesotho for a period 1970-2012, by employing Granger causality test, ARDL and VECM. Results of this study confirmed that ECNG granger causes savings in the short-run and in the savings does granger cause ECNG. In addition, a bidirectional causality is also observed among investment and ECNG. 
By using various statistical techniques for obtaining empirical evidence, researchers supported that trade has a significant positive impact on ECNG. Therefore, to analyze the association among trade, ECNG (per capital GDP) and FDI in Bangladesh, Hussain and Haque (2016) used the data for 1973-2014 to perform VECM analysis. The result of the statistical analysis has shown that positive relation exists between trade and FDI and ECNG. Furthermore, for analyzing the trade-ECNG linkage in Peru, Argentina and Columbia, Fapetu and Owoeye (2017) also performed a Granger causality test and reported that these economies are based more upon the import-based growth as compared to export-based growth. It has also found one-way causality between trade and GDP, running from GDP to imports and exports. Another study Hakimi and Hamdi (2016) also tried to investigate the trade-ECNG relationship by using the data for 100 developing and developed economies for the time period 1970-1997, and employed a panel data approach for the statistical estimation. The findings revealed significant positive effects the trade barriers pose on the ECNG, particularly in developing economies.

In addition, You (2017) performed the multivariate causality tests for investigating the imports and exports and FDI's impact on GDP in 9 Asian economies including Indonesia, Hong Kong, India, South Korea, Singapore, Malaysia, Philippines, Taiwan and Thailand, using a VECM analysis. The study revealed a bidirectional causality among FDI, growth and trade in most of the countries involved in this study.

On the other hand, author has failed to find any cause and effect relationship between domestic savings and ECNG in Cambodia during 1989-2012. Besides, the study also used the unit root test. Therefore, to observe how savings influence ECNG in five Asian economies, including South Korea, Thailand, Singapore, Philippines, and Malaysia, (Liew \& Tang, 2019) employed the data for the time period 1960-1997 and applied the time series analysis. The results obtained from Granger causality test indicated no causality from savings to ECNG, however, a causality from foreign savings to domestic savings was found in the long-run. By employing a Johansen cointegration technique, Nwanne (2016) attempted to examine whether the savings pattern in Nigeria influenced its ECNG, during 1970-2007, and concluded that savings and ECNG are cointegrated. Results have also shown that ECNG granger causes savings that implies, the higher the ECNG the greater will be the savings. Another empirical research conducted by Shubita (2015) applied an ARDL approach to identify the ECNG-savings relationship for Tunisian economy, for a period of 1961-2007, and in Morocco during 1965-2007. He found long-run association and bidirectional causal relationship among savings and ECNG in Morocco, and one-way causal relationship exists which runs from savings to GDP in Tunisia.

Wagner's Law was first introduced more than a century ago. Many researchers agree with Wagner's Law. However, there are scholars who support Keynesian theory. Fasoranti (2015) has both empirical support of Wagner's Law and Keynesian view in Malaysia. Findings about the relationship between government expenditure and ECNG is also different among scholars due to data selection, methodological differences and estimating procedures. Since many researchers used time-series technique, this study provides panel data approach to give more understanding about the significant relationship between public spending and economic development for ASEAN-5 countries. Previous studies also show different findings about the impact of other macroeconomic variables such as capital formation, portfolio investment, labor force, trade, total reserve and savings on ECNG.

\section{Measurement}

The empirical analysis of this study uses annual data on ASEAN-5 countries from year 1990 to 2014. The countries are Thailand, Singapore, Indonesia, Philippines and Malaysia. The basic data source of this study is World Development Indicators from the official website of the World Bank. By using balanced panel data, the dependent variable of the study is gross domestic product (GDP). GDP is used to measure the ECNG. This study provides three models of the research. All models use GDP as dependent variable. For Model there are five independent variables; government expenditure, gross capital formation, portfolio investment, labor, trade, total reserve and gross savings. 
At purchaser's price, the GDP is measured in US dollars which is the aggregate gross value added of all home country producers by including the product taxes and by excluding any subsidies that should be added in products' value (World Bank, 2017; OECD National Accounts, 2017). It is generally measured without excluding the cost of depreciation for any fabricated assets and the cost for natural resource depletion. By using official exchange rate for only one year, the domestic currency figures are converted into dollars.

The current study used general government's final consumption (in terms of US dollars) in order to determine the total GSP. The term was initially known as a general government consumption, which comprises of the current GSP on goods and services plus employees' compensation expenses, and the expenses on national security and defense, minus the expenses on government military (OECD National Accounts data, and World Bank database, 2017). The aim of this research is to investigate whether there is positive relationship existing among ECNG and government expenditure.

The term Gross capital formation, initially termed as the gross domestic investment is comprised of expenditures other than the fixed assets plus the net changes in inventories, where the inventories refer to product stocks that are kept by firms in order to deal with unexpected or temporary fluctuations in sales or production and the fixed assets accounts for the plant, equipment purchases, machinery, construction of railways, schools, hospitals, offices, private residence, industrial and commercial buildings, and land improvements.

This study also included portfolio investment which involves transactions of debt and equity securities and is measured in US dollars. Therefore, a positive relationship is expected to exist between ECNG and portfolio investment. Labor force includes all the population with ages 15 and above, and who satisfies the definition proposed by International Labour Organization, i.e. all individuals who are economically active or supply labor in the goods and services production, during a certain time period. Labor force also includes first-time job seekers, armed forces and the unemployed, however, it excludes unpaid caregivers, informal sector employees, and homemakers (International Labour Organization, 2017).

Moreover, the trade represents the aggregate of imports and exports of goods and services and is taken as a percentage of GDP (OECD National Accounts data files, 2017; World Bank, 2017). A surplus or positive trade balance of a country indicates that the exports value exceeded the imports value, whereas, a negative trade deficit or trade balance indicates that the value of imports is greater as compared to the value of exports (Focus Economics, 2017). Therefore, a country's gross savings are measured as the total gross national income (GNI), by including net transfers and excluding total consumption.

The main objective of the study is to determine the impact of government expenditure on ECNG for ASEAN-5 countries. The countries involved are Thailand, Singapore, Indonesia, Philippines and Malaysia. It also investigates the impact of other macroeconomic variables on ECNG for ASEAN-5 countries. The variables are gross capital formation, portfolio investment, labor force, trade, total reserve and gross savings. The data was obtained from year 1990 to 2014. This study shows that government expenditure does have positive significant impact on ECNG. All macroeconomic variables, such as gross capital formation, portfolio investment, labor force, total reserves and gross savings also have positive relationship with ECNG. Only trade has negative significant impact on GDP. The findings are parallel with previous empirical studies of Ayinde et al. (2015) and Mohammadi and Ram (2015).

\section{Data}

The empirical analysis of this study uses annual data on ASEAN-5 countries from year 1990 to 2014. The countries are Thailand, Singapore, Indonesia, Philippines and Malaysia. The basic data source of this study is World Development Indicators from the official website of the World Bank. By using balanced panel data, the dependent variable of the study is gross domestic product (GDP). GDP is used to measure the ECNG. This study provides three models of the research. All models use GDP as dependent variable. For Model 1, there are seven independent variables; government expenditure, gross capital formation, portfolio investment, labor, 
trade, total reserve and gross savings. Model 2 and Model 3 have five independent variables; government expenditure, gross capital formation, labor, total reserve and gross savings.

\section{Econometric model}

The following model is used to investigate the impact of government expenditure, gross capital formation, portfolio investment, labor force, trade, total reserve and gross savings on gross domestic products. The equation is presented as follows:

$$
\mathbf{G D P}=\mathrm{f}(\mathrm{GEXP}, \mathrm{GCF}, \mathrm{PI}, \mathrm{LBR}, \mathrm{TRD}, \mathrm{TRSV}, \mathrm{GSV}) \ldots(1)
$$

where, GDP is Gross Domestic Products, GEXP is Government Expenditure, GCF is Gross Capital Formation, PI is Portfolio Investment, LBR is Labor Force, TRD is Trade, TRSV is Total Reserves and GSV is Gross Savings. GDP is the dependent variable and other variables are independent variables. The econometric models of GDP function are shown as follows:

$$
\mathbf{Y}=\beta \mathrm{o}+\beta 1 \mathrm{X} 1 \mathrm{it}+\beta 2 \mathrm{X} 2 \mathrm{it}+\beta 3 \mathrm{X} 3 \mathrm{it}+\beta 4 \ln \mathrm{X} 4 \mathrm{it}+\beta 5 \mathrm{X} 5 \mathrm{it}+\beta 6 \mathrm{X} 6 \mathrm{it}+\beta 7 \mathrm{X} 7 \mathrm{it}+\mathrm{eit} \ldots(2)
$$

For Model 1, the econometric model is:

$$
\begin{gathered}
\mathbf{L G D P}=\beta \mathrm{o}+\beta 1 \ln (\mathrm{GEXP})+\beta 2 \ln (\mathrm{GCF})+\beta 3 \ln (\mathrm{PI})+\beta 4 \ln (\mathrm{LBR})+\beta 5 \ln (\mathrm{TRD})+ \\
\beta 6 \ln (\mathrm{TRSV})+\beta 7 \ln (\mathrm{GSV})+\operatorname{eit} . .(3)
\end{gathered}
$$

where, GDP is Gross Domestic Products, GEXP is Government Expenditure, GCF is Gross Capital Formation, PI is Portfolio Investment, LBR is Labor Force, TRD is Trade, TRSV is Total Reserves, GSV is Gross Savings, eit is the error term and $\ln$ is the natural logarithms.

For Model 2, the econometric model is:

$$
\mathbf{L G D P}=\beta o+\beta 1 \ln (\mathrm{GEXP})+\beta 2 \ln (\mathrm{GCF})+\beta 3 \ln (\mathrm{LBR})+\beta 4 \ln (\mathrm{TRSV})+\beta 5 \ln (\mathrm{GSV})+\text { eit } \ldots \text { (4) }
$$

where, GDP is Gross Domestic Products, GEXP is Government Expenditure, GCF is Gross Capital Formation, LBR is Labor Force, TRSV is Total Reserves, GSV is Gross Savings, cit is the error term and $\ln$ is the natural logarithms. For Model 3, the econometric model is:

$$
\mathbf{G D P}=\beta \mathrm{o}+\beta 1(\mathrm{GEXP})+\beta 2(\mathrm{GCF})+\beta 3(\mathrm{LBR})+\beta 4(\mathrm{TRSV})+\beta 5(\mathrm{GSV})+\text { eit } \ldots . .(5)
$$

where, GDP is Gross Domestic Products, GEXP is Government Expenditure, GCF is Gross Capital Formation, LBR is Labor Force, TRSV is Total Reserves, GSV is Gross Savings and eit is the error term.

The pretesting problem that is indirectly involved in the cointegration analysis can be avoided by the ARDL approach. There is no priori exogenous and endogenous division of variables in the model. Likewise, zero restrictions are not forced and no strict theory of economic in which the model is developed. In addition, a dynamic ECM can be derived from this approach through a simple linear transformation. However, to illustrate ARDL model approach, this model is considered. 


$$
\begin{aligned}
\Delta \boldsymbol{G D P}_{t}=\frac{a_{0}}{\mu(1)} & +a_{1} G E X R_{t}+a_{2} G C F_{t}+a_{3} L B R_{t}+a_{4} T R S V_{t}+a_{5} G S V_{t}+\frac{1}{\mu(1)} \sum_{i=1}^{m_{1}-1} a_{1} \Delta G E X R_{t-1} \\
& +\frac{1}{\mu(1)} \sum_{i=1}^{m_{2}-1} a_{2} \Delta G C F_{t-1}+\frac{1}{\mu(1)} \sum_{i=1}^{m_{3}-1} a_{3} \Delta L A B_{t-1}+\frac{1}{\mu(1)} \sum_{i=1}^{m_{4}-1} a_{4} \Delta T R S V_{t-1} \\
& +\frac{1}{\mu(1)} \sum_{i=1}^{m_{5}-1} a_{5} \Delta G S V_{t-1}+\varepsilon_{t} \ldots \ldots(6)
\end{aligned}
$$

\section{Results}

The results of the correlation test between dependent variable and independent variables proved to be very useful in pre estimation analysis especially as regards potential relationships suggested by theories. Therefore prior to the econometrics analysis, the statistical correlation of the variables are examined which helped in determining the statistical relationships between and amongst the variables.

Table 1. Correlation Analysis

\begin{tabular}{|c|c|c|c|c|c|c|c|}
\hline & & $\mathbf{1}$ & $\mathbf{2}$ & $\mathbf{3}$ & $\mathbf{4}$ & $\mathbf{5}$ & $\mathbf{6}$ \\
\hline GDP & $\mathbf{1}$ & 1 & & & & & \\
\hline GEXP & $\mathbf{2}$ & $0.830^{* *}$ & 1 & & & & \\
\hline GCF & $\mathbf{3}$ & $0.257^{* *}$ & $0.243^{* *}$ & 1 & & & \\
\hline LBR & $\mathbf{4}$ & $0.810^{*}$ & $0.118^{* *}$ & $0.829^{*}$ & 1 & & \\
\hline TRSV & $\mathbf{5}$ & $0.145^{* *}$ & $0.463^{*}$ & 0.129 & $0.579^{*}$ & 1 & \\
\hline GSV & $\mathbf{6}$ & $0.130^{*}$ & $0.247^{* *}$ & 0.828 & $0.674^{*}$ & 0.882 & 1 \\
\hline
\end{tabular}

Table 2 summarize the results of GDP, export models respectively based on the selected ARDL models. An ARDL $(1,0,0,1,1,1,0,1)$ was chosen for the GDP model. The results of R2 (78.7\%), the adjusted R2 (65.9\%) in Table 2 along with the F-statistic for GDP equation model show that the model obtained best goodness of fit and variations of the selected independent variables explained certain the changes of the dependent variable. The significance of the F-statistics test justifies the inclusion of all the explanatory variables existing in the

\begin{tabular}{|c|c|c|c|c|}
\hline Variables & Coefficients & Standard Error & $t$-statistics & $p$-Value \\
\hline \multicolumn{5}{|c|}{ Model 1: ARDL $(1,0,1,0,1)$} \\
\hline GEXP & 0.415 & 0.142 & 2.922 & $0.008^{*}$ \\
\hline GEXP(-1) & 0.455 & 0.147 & 3.090 & $0.006^{*}$ \\
\hline GCF & 0.000 & 0.000 & 2.427 & $0.024 *$ \\
\hline LBR & 0.000 & & 5.938 & $0.000 *$ \\
\hline LBR(-1) & -0.477 & 0.137 & -3.498 & $0.002 *$ \\
\hline TRSV & 0.001 & 0.001 & 2.202 & $0.003 * *$ \\
\hline GSV & 0.023 & 0.043 & 3.526 & 0.000 \\
\hline GSV(-1) & 0.065 & 0.037 & 1.763 & $0.092 * *$ \\
\hline $\mathrm{C}$ & 7.406 & 2.882 & 2.570 & $0.018^{*}$ \\
\hline $\mathbf{T}$ & 0.045 & 0.009 & 4.731 & $0.000^{* * *}$ \\
\hline
\end{tabular}
GDP model.

Table 2. Optimal ARDL Model Selection 
Findings about the relationship between government expenditure and ECNG is also different among scholars due to data selection, methodological differences and estimating procedures. This study uses panel data approach from year 1990 to 2014 for ASEAN-5 countries. The findings are discussed in chapter four. The future research is expected to explore different methods to confirm the reliability of the model. From this study, there is evidence that government expenditure does have impact on ECNG. Future research is expected to expand the investigation to other composition of GSP such as education, defense and infrastructure expenditures instead of using general government final consumption expenditures.

\section{Conclusion}

The issue of GSP and ECNG is crucial for developing countries. As mentioned by Odhiambo (2018) the public sector usually uses a relatively large share of society's economic resources. The government of a country need to spend more on regulations as the urbanization and economic development increase. The allocation of GSP is also important on certain services such as cultural and welfare. These services are considered as high-income elasticity. The GSP may contribute positively to ECNG through its interaction with the private sector. The government provides large-scale capital expenditures since the private sector does not have the capacity to provide the funds; as stated by Pradhan et al. (2015). Increase in government consumption may increase in employment, profitability and investment of a country. GSP is increasing over the years. Naseer (2019) conclude that productive PEXs may become unproductive if misallocating and using it in excess. Evidence from Kurniawan (2016) shows that fiscal stimulus does contribute to rapid economy recovery in the ASEAN-5 countries after the financial crisis in 2008. The GSP of ASEAN-5 countries on infrastructure is the major contribution to increase the overall investment and ECNG. Thus, ASEAN Blueprint 2025 is implemented to integrate the regional economic agenda for ASEAN countries. ASEAN governments are expected to spend productively with closely monitored implementation of AEC Blueprint 2025 towards a healthy economic development.

This paper examines the impact of public spending on ASEAN-5 countries economic development. The purpose of this study is to provide evidence, reference and contribute to the knowledge about GSP and ECNG. It is expected to clarify the importance of fiscal policy and other macroeconomic variables in strengthening the economy for ASEAN-5 countries. A clear understanding about inter-linkages between GSP and ECNG will help the government in making better decision for the country. As ASEAN countries have responsibility for ASEAN Economic Community (AEC) Blueprint 2025 to meet its objectives, ASEAN governments are expected to effectively monitor the public spending as fiscal instrument in stimulating ECNG. Government expenditure may become unproductive if misallocating and using it in excess, as suggested by Naseer (2019).

A clear understanding about inter-linkages between GSP and ECNG will help the government in making better decision for the country. As ASEAN countries have responsibility for ASEAN Economic Community (AEC) Blueprint 2025 to meet its objectives, ASEAN governments are expected to effectively monitor the public spending as fiscal instrument in stimulating ECNG. Government expenditure may become unproductive if misallocating and using it in excess, as suggested by Naseer (2019). Findings about the relationship between government expenditure and ECNG is also different among scholars due to data selection, methodological differences and estimating procedures. This study uses panel data approach from year 1990 to 2014 for ASEAN-5 countries. The future research is expected to ex+plore different methods to confirm the reliability of the model. From this study, there is evidence that government expenditure have impact on ECNG. Future research is expected to expand the investigation to other composition of GSP such as education, defense and infrastructure expenditures instead of using general government final consumption expenditures. 


\section{References}

Abdul Hadi, A.R., Zainudin, Z., Hussain, H.I. \& Rehan, R., (2019) Interaction of Short-Term and Long-Term Interest Rates in Malaysian Debt Markets - Application of Error Correction Model and Wavelet Analysis, Asian Academy of Management Journal, 24 (Supp. 1), 19 - 31. https://doi.org/10.21315/aamj2019.24.s1.2

Ajayi, M. A., \& Aluko, O. A. (2016). The Causality between Government Expenditure and Economic Growth in Nigeria: A TodaYamamoto Approach. Journal of Economics \& Business Research, 22(2).

Ayinde, O. E., Ilori, T., Ayinde, K., \& Babatunde, R. (2015). Analysis of the Behaviour of prices of major staple foods in West Africa: A case study of Nigeria. Agris on-line Papers in Economics and Informatics, 7(665-2016-45069), 3-17.

Baltgailis, J. (2019). The issues of increasing the effectiveness of teaching comparative economics, Insights into Regional Development 1(3): 190-199. https://doi.org/10.9770/ird.2019.1.3(1)

Demirci, M. N., Soon, J. M., \& Wallace, C. A. (2016). Positioning food safety in Halal assurance. Food Control, 70, 257-270. https:// doi.org/10.1016/j.foodcont.2016.05.059

Donou-Adonsou, F. (2019). Technology, education, and economic growth in Sub-Saharan Africa. Telecommunications Policy, 43(4), 353-360. https://doi.org/10.1016/j.telpol.2018.08.005

Fapetu, O., \& Owoeye, S. D. (2017). Testing the validity of the export-led growth hypothesis in Nigeria: Evidence from non-oil and oil exports. Computational Methods in Social Sciences, 5(2), 41-48.

Fasoranti, M. (2015). An econometric analysis of the determinants of government health expenditures in Nigeria. Journal of Empirical Economics, 4(4), 193-206.

Fawwaz, T. M. (2016). The impact of government expenditures on economic growth in Jordan (1980-2013). International Business Research, 9(1), 99.

Hakimi, A., \& Hamdi, H. (2016). Trade liberalization, FDI inflows, environmental quality and economic growth: a comparative analysis between Tunisia and Morocco. Renewable and Sustainable Energy Reviews, 58, 1445-1456. https://doi.org/10.1016/j.rser.2015.12.280

Hussain, M., \& Haque, M. (2016). Foreign direct investment, trade, and economic growth: An empirical analysis of Bangladesh. Economies, 4(2), 7 .

Jakovljevic, M. M. (2016). Comparison of historical medical spending patterns among the BRICS and G7. Journal of medical economics, 19(1), 70-76. https://doi.org/10.3111/13696998.2015.1093493

Kleven, H. J., Kreiner, C. T., \& Saez, E. (2016). Why can modern governments tax so much? An agency model of firms as fiscal intermediaries. Economica, 83(330), 219-246. https://doi.org/10.1111/ecca.12182

Kurniawan, R. (2016). Essays on tax smoothing and fiscal policy sustainability in Indonesia.

Liew, C. T., \& Tang, T. C. (2019). New Go South Policy: Are Exports and Imports of Taiwan with ASEAN10 Cointegrated? Contemporary Chinese Political Economy and Strategic Relations, 5(1), 333-XII. https://theasiadialogue.com/wp-content/uploads/2017/11/ bf078c01-1e89-457a-a842-548e421d7820.pdf

Mohamed, B. M., Rasheli, G. A., \& Mwagike, L. R. (2018). Marginal Effects of Factors Influencing Procurement Records Management: A Survey of Selected Procuring Entities in Tanzania. International Journal of Social and Administrative Sciences, 3(1), $22-34$.

Mohammed, Z. (2017). Impact of Sexual Lifestyle on Hormone-Related Health Decline Case Married Teachers. International Journal of Social Sciences Perspectives, 1(1), 1-5. https://doi.org/10.33094/7.2017.11.1.5

Mujtaba, M., Jamal, S., Qureshi, J. A., \& Shaikh, Y. (2018). Human Capital is a Competitive Advantage of Businesses: Analysis of Automobile Firms of Pakistan. Asian Themes in Social Sciences Research, 2(1), 16-22. https://doi.org/10.33094/journal.139.2018.21.16.22

Mulyani, S. (2017). Pregnant Women with Extended Family on Knowledge, Motivation, and Readiness In Exclusive Breastfeeding. International Journal of Emerging Trends in Social Sciences, 1(2), 104-107. https://doi.org/10.33094/journal.139.2018.21.16.22

Mohammadi, H., \& Ram, R. (2015). Economic development and government spending: An exploration of Wagner's hypothesis during fifty years of growth in East Asia. Economies, 3(4), 150-160.

Naseer, S. (2019). Public Spending, Quality of Bureaucracy and Economic Growth: A Theoretical Analysis. The Pakistan Development Review, 58(2), 203-221. 
Nishiyama, Y. (2019). Causality between government spending and income: the case of Saudi Arabia. Applied Economics Letters, 26(5), 433-435.

Nwanne, T. (2016). Implication of Savings and Investment on Economic Growth in Nigeria. International Journal of Small Business and Entrepreneurship Research, 2(4), 74-86. http://www.eajournals.org/wp-content/uploads/Implications-of-Savings-and-Investmenton-Economic-Growth-in-Nigeria.pdf

Nazal, A. I. (2017). Financial tables reports gaps in Jordanian Islamic Banks. The Economics and Finance Letters, 4(2), 9-15.

Negrut, V. (2017). Overview of the Most Common Types of Maladministration Raised at EU Level. International Journal of Public Policy and Administration Research, 4(2), 35-40.

Njegovanovic, A. (2018). Hilbert Space/Quantum Theory of the Financial Decision and Role of the Prefrontal Cortex with a View to Emotions. International Journal of Social and Administrative Sciences, 3(1), 42-54.

Okon, E. O. (2017). Climate Change: Space Technology and Climate-Resilient Development in Nigeria. International Journal of Social Sciences Perspectives, 1(1), 6-19. https://doi.org/10.33094/7.2017.11.6.19

Okon, E. O., \& Monday, O. I. (2017). Empirical and evidence-based investigation: External debt, poverty and economic growth nexus. International Journal of Applied Economics, Finance and Accounting, 1(1), 37-47.

Odhiambo, N. M. (2018). Public expenditure and economic growth in Kenya: A multivariate dynamic causal linkage.

Pastor, M. (2019). Inflation, stabilization, and debt: Macroeconomic experiments in Peru and Bolivia: Routledge.

Pinder, D. (2017). Regional economic development and policy: Theory and practice in the European Community: Routledge.

Pradhan, R. P., Arvin, M. B., \& Norman, N. R. (2015). The dynamics of information and communications technologies infrastructure, economic growth, and financial development: Evidence from Asian countries. Technology in Society, 42, 135-149. https://doi. org/10.1016/j.techsoc.2015.04.002

Ruiz, J. L. (2018). Financial development, institutional investors, and economic growth. International Review of Economics \& Finance, $54,218-224$.

Russell, H., N. Hayley, P. Marissa and Nicole, P. (2017). Mental health in Australian (North Queensland) tertiary students. International Journal of Innovation, Creativity and Change, 3(3): 105-123.

Ryan, D. and Robert, J. (2017). A preliminary exploration of frameworks for building artists' resilience. International Journal of Innovation, Creativity and Change, 3(3): 89-104.

Sáez, M. P., Álvarez-García, S., \& Rodríguez, D. C. (2017). Government expenditure and economic growth in the European Union countries: New evidence. Bulletin of Geography. Socio-economic Series, 36(36), 127-133.

Sasongko, G., Huruta, A.D., Wardani, A. (2019). Does the Wagner's Law exist in a strategic national area? An evidence from Kedungsepur - Indonesia. Insights into Regional Development, 1(2), 99-117. https://doi.org/10.9770/ird.2019.1.2(2)

Sekantsi, L. P., \& Kalebe, K. M. (2015). Savings, investment and economic growth in Lesotho: An empirical analysis. Journal of economics and international finance, 7(10), 213-221.

Shubita, M. F. (2015). The impact of income smoothing on earnings quality in emerging markets: Evidence from GCC markets. Journal of accounting in emerging economies, 5(3), 299-324. https://www.abacademies.org/articles/the-impact-of-income-smoothing-on-taxprofit-an-applied-study-to-a-sample-of-international-companies-7586.html

Thabane, K., \& Lebina, S. (2016). Economic growth and government spending nexus: Empirical evidence from Lesotho. African Journal of Economic Review, 4(1), 86-100.

Tung, L. T. (2019). Role of Unemployment insurance in Sustainable development in Vietnam: Overview and policy implication. Entrepreneurship and Sustainability Issues, 6(3), 1039-1055. http://doi.org/10.9770/jesi.2019.6.3(6)

Wang, S., Li, G., \& Fang, C. (2018). Urbanization, economic growth, energy consumption, and CO2 emissions: Empirical evidence from countries with different income levels. Renewable and Sustainable Energy Reviews, 81, 2144-2159.

You, K. (2017). What drives outward Fdi of China?: A regional analysis. The Journal of Developing Areas, 51(2), $239-253$. 
Kittisak JERMSITTIPARSERT holds Ph.D. in Social Sciences (major in Political Science) from Kasetsart University, Thailand. He is currently a researcher at Chulalongkorn University Social Research Institute, a part-time researcher at Ton Duc Thang University, and the secretary general of Political Science Association of Kasetsart University. His areas of expertise are Political Science, Public and Business Administration, and Interdisciplinary Research in Social Sciences.

Sakapas SAENGCHAI is studying Ph.D. in Public Administration at Ramkhamhaeng University Thailand. He currently is Assistant Professor in Public Administration at the Faculty of Humanities and Social Sciences, Suan Sunandha Rajabhat University. His areas of expertise are Public and Private Administration and Interdisciplinary Studies in Social Sciences.

Chanathat BOONRATTANAKITTIBHUMI holds Ph.D. in Management from Siam University Thailand. He currently is a lecturer at King Moungkult's Institute of Technology, Prince of Chumphon Campus, Thailand. His research areas are in Management, Strategy Management, Social Enterprise, Organizations, Business Model, Agribusinesses, and Tourism.

Thitinan CHANKOSON is an Assistant Professor of Business Administration at the Faculty of Business Administration for Society, Srinakharinwirot University, Thailand. He holds a Doctor of Science in International Service Business Management from North Eastern University, Thailand. His research interests are service business management, aviation management, international business management, supply chain management, and tourism and hospitality industry.

Register for an ORCID ID:

https://orcid.org/register

This work is licensed under the Creative Commons Attribution International License (CC BY).

http://creativecommons.org/licenses/by/4.0/ 